\title{
Mitigation of Commercial Food Waste-Related Salinity Stress Using Halotolerant Rhizobacteria in Chinese Cabbage Plants
}

\author{
Muhammad Aaqil Khan ${ }^{1}$, Kalsoom ${ }^{1}$, Muhammad Imran ${ }^{1}$, Lubna $^{2}$, Shifa Shaffique ${ }^{1}$, Eun-Hae Kwon ${ }^{1}$, \\ Sang-Mo Kang ${ }^{1}$, Seong-Heon Kim ${ }^{3}$, Muhammad Hamayun ${ }^{2}$ and In-Jung Lee ${ }^{1, *}$ \\ 1 Department of Applied Biosciences, Kyungpook National University, Daegu 41566, Korea; \\ aqil_bacha@knu.ac.kr (M.A.K.); kalsoom_bacha@yahoo.com (K.); m.imran02@knu.ac.kr (M.I.); \\ Shifa.2021@knu.ac.kr (S.S.); rnjsdmsgo10@knu.ac.kr (E.-H.K.); sangmo@knu.ac.kr (S.-M.K.) \\ 2 Department of Botany, Abdul Wali Khan University, Mardan 23200, Pakistan; lubnabilal88@gmail.com (L.); \\ hamayun@awkum.edu.pk (M.H.) \\ 3 National Institute of Agricultural Science, Rural Development Administration, Wanju 55365, Korea; \\ ksh4054@korea.kr \\ * Correspondence: ijlee@knu.ac.kr
}

Citation: Khan, M.A.; Kalsoom; Imran, M.; Lubna; Shaffique, S.; Kwon, E.-H.; Kang, S.-M.; Kim, S.-H.; Hamayun, M.; Lee, I.-J. Mitigation of Commercial Food Waste-Related Salinity Stress Using Halotolerant Rhizobacteria in Chinese Cabbage Plants. Horticulturae 2022, 8, 49. https://doi.org/10.3390/ horticulturae8010049

Academic Editor: Alessandra Francini

Received: 2 November 2021

Accepted: 9 December 2021

Published: 5 January 2022

Publisher's Note: MDPI stays neutral with regard to jurisdictional claims in published maps and institutional affiliations.

Copyright: (C) 2022 by the authors Licensee MDPI, Basel, Switzerland. This article is an open access article distributed under the terms and conditions of the Creative Commons Attribution (CC BY) license (https:// creativecommons.org/licenses/by/ $4.0 /)$.

\begin{abstract}
The use of commercial food waste in the Korean agricultural industry is increasing due to its capacity to act as an ecofriendly fertilizer. However, the high salt content of food waste can be detrimental to plant health and increase salinity levels in agricultural fields. In the current study, we introduced halotolerant rhizobacteria to neutralize the negative impact of food waste-related salt stress on crop productivity. We isolated halotolerant rhizobacteria from plants at Pohang beach, and screened bacterial isolates for their plant growth-promoting traits and salt stress-mitigating capacity; consequently, the bacterial isolate Bacillus pumilus MAK9 was selected for further investigation. This isolate showed higher salt stress tolerance and produced indole-3-acetic acid along with other organic acids. Furthermore, the inoculation of B. pumilus MAK9 into Chinese cabbage plants alleviated the effects of salt stress and enhanced plant growth parameters, i.e., it increased shoot length (32\%), root length $(41 \%)$, fresh weight $(18 \%)$, dry weight (35\%), and chlorophyll content $(13 \%)$ compared with such measurements in plants treated with food waste only (control). Moreover, relative to control plants, inoculated plants showed significantly decreased abscisic acid content (2-fold) and increased salicylic acid content (11.70\%). Bacillus pumilus MAK9-inoculated Chinese cabbage plants also showed a significant decrease in glutathione (11\%), polyphenol oxidase $(17 \%)$, and superoxide anions $(18 \%)$, but an increase in catalase $(14 \%)$, peroxidase $(19 \%)$, and total protein content $(26 \%)$ in comparison to the levels in control plants. Inductively coupled plasma mass spectrometry analysis showed that B. pumilus MAK9-inoculated plants had higher calcium (3\%), potassium (22\%), and phosphorus $(15 \%)$ levels, whereas sodium content $(7 \%)$ declined compared with that in control plants. Similarly, increases in glucose $(17 \%)$, fructose $(11 \%)$, and sucrose $(14 \%)$ contents were recorded in B. pumilus MAK9-inoculated plants relative to in control plants. The bacterial isolate MAK9 was confirmed as B. pumilus using $16 \mathrm{~S}$ rRNA and phylogenetic analysis. In conclusion, the use of commercially powered food waste could be a climate-friendly agricultural practice when rhizobacteria that enhance tolerance to salinity stress are also added to plants.
\end{abstract}

Keywords: $\mathrm{NaCl}$ stress; plant growth-promoting bacteria; antioxidants; phytohormones; ion uptake

\section{Introduction}

Food waste refers to all uneaten but disposed of food substances or leftovers from households, markets, supermarkets, and various eating establishments [1]. More than one third of food generated for human consumption [2,3] and nearly 1.3 billion tons of food are estimated to be lost in the food supply chain [4,5]. Up to $42 \%$ of food waste is produced by households, whereas 39\% comes from food manufacturing industries, $14 \%$ from the food service sector, and 5\% from the distribution process [6]. Food waste levels 
are expected to increase within 25 years due to economic and population growth, especially in Asian countries, rising from 278 to 416 million tons from 2005 to 2025 [4,7]. In Japan and Taiwan, 19 million and 16.5 million tons of food is wasted annually, respectively $[7,8]$. In Korea, food waste reportedly comprises $>22 \%$ (4.3 million tons) of municipal solid waste [9]. Together with other waste products, food waste can give rise to problems such as emanating odors, attracting vermin, emitting toxic gas, and contaminating groundwater [10]. Thus, such waste must be removed to ensure that the environment is clean and healthy.

Composting is a simple, economical, and natural biodegradation process that can convert food waste into a stable, hygienic, humus-rich, and nutrient-rich food for plants [7], which can also stabilize and enhance the properties of the soil to which it is applied [11]. Recycling food waste is now a public concern as it is an environmentally sound and cost effective use of waste biomass [12,13]. In Japan, food waste recycling accounts for only $6.7 \%$ of recycling compared with $78 \%$ for industrial waste recycling [14]. Nevertheless, food waste contains important nutrients that could be efficiently reused in agriculture [12,15], i.e., to improve soil properties, the growth and development of plants, and agricultural productivity [16,17]. The constituents of food waste generally include carbohydrates, protein, and inorganic compounds, which serve as food for microbes [18]. Thus, the integration of biofertilizers with organic fertilizers can be beneficial [14].

However, the application of food waste as a fertilizer for agricultural purposes has some disadvantages [19]. For example, it has been reported that soil salinity increases due to the decomposition of food waste [20]. Lee et al. [20] reported respective average water and salinity contents of $72.00 \%$ and $2.03 \%$ in collected food waste from Korea. Soil salinity can be a devastating environmental stressor: it can reduce cultivated land area, crop productivity, and crop quality [21]. Salinity stress also effects the morphological, physiological, and biochemical process of plants, including their seed germination, growth, and nutrient uptake [6]. Salinity stress is estimated to affect $20 \%$ and $33 \%$ of all cultivated and irrigated land worldwide, respectively [22]. Under salt stress conditions, reactive oxygen species (ROS), such as superoxide radicals, hydroxyl radicals, and hydrogen peroxide, are produced and accumulate in plant cellular compartments, thereby causing oxidative damage [23]. To counteract ROS-mediated oxidative stress, plants have developed enzymatic and nonenzymatic systems that protect their cells and help maintain ROS at normal levels [23]. Plants under salinity stress accumulate $\mathrm{Na}$ and suffer inhibition of the uptake of nutrients such as $\mathrm{Ca}, \mathrm{K}$, and $\mathrm{P}$, which are vital to the maintenance of cell membranes [22]. In soybean and tomato plants, salinity stress decreases growth attributes and productivity $[24,25]$. As a potential solution, plant growth-promoting rhizospheric bacteria have been reported to mitigate salinity stress and enhance crop yield in various plants $[24,26,27]$.

Therefore, in current study, we hypothesized that the use of powdered food waste with the inoculation of salt-tolerant plant growth-promoting bacteria could be an ecofriendly agricultural practice that enhances the salinity stress tolerance of plants. Specifically, rhizospheric bacteria were isolated and screened for plant growth-promoting traits, e.g., siderophore production, phosphate solubilization, indole-3-acetic acid (IAA) production, and exopolysaccharide (EPS) production, as well as tolerance to $\mathrm{NaCl}$ stress. Based on multiple plant growth-promoting traits and salt tolerance, the bacterial isolate MAK9 was selected and identified using 16S rRNA analysis. The objective of the current study was then to understand the effects on the growth and chlorophyll content of Chinese cabbage plants when applying food waste with and without inoculation of the isolate MAK9. In addition, we aimed to elucidate the translocation of ion uptake $\left(\mathrm{Na}^{+}, \mathrm{K}^{+}, \mathrm{Ca}\right.$, and $\left.\mathrm{P}\right)$, antioxidant production, and phytohormone content (abscisic acid [ABA] and salicylic acid [SA]) of Chinese cabbage plants treated with food waste with and without the isolate MAK9.

\section{Materials and Methods}

\subsection{Plant Material and Isolation of Rhizospheric Bacteria}

Different plants species (Artemisia princeps, Echinochloa crus-galli, Chenopodium ficifolium, and Oenothera biennis) were collected from the sand dunes of Pohang beach $\left(36^{\circ} 7^{\prime} 56.2^{\prime \prime} \mathrm{N}\right.$, 
$129^{\circ} 23^{\prime} 55.1^{\prime \prime}$ E) in Korea. The plants were packed in sterilized polyethylene zip bags along with rhizospheric soil. Subsequently, $1 \mathrm{~g}$ of rhizospheric soil taken from the root of individual plants was used for serial dilution. Petri plates were covered with Parafilm and kept in an incubator at $27^{\circ} \mathrm{C}$.

\subsection{Screening Rhizobacterial Isolates for Plant Growth Promotion}

Rhizospheric bacterial isolates were grown for IAA production in $50 \mathrm{~mL}$ of LB media at $30{ }^{\circ} \mathrm{C}$ with shaking at $120 \mathrm{rpm}$ for 6 days. Salkowski reagent was used for IAA detection and UV absorbance was assessed with a UV spectrophotometer (Multiskan GO, Thermo Fisher Scientific, Vantaa, Finland) at $530 \mathrm{~nm}$ [28]. For phosphate solubilization and siderophore production, rhizospheric bacteria were inoculated into Petri dishes with Pikovskaya's medium and Chrome Azurol S (CAS) medium, and incubated for 5 days at $27^{\circ} \mathrm{C}$ according to the method of Chadha et al. [28]. For detection of bacterial EPS, we followed the method of Yu-Na et al. [29].

\subsection{Screening of MAK9 for Halotolerance and Bacterial Identification}

Rhizospheric bacterial isolates were tested for halotolerance at different $\mathrm{NaCl}$ concentrations. In LB medium, the bacterial isolates were grown and supplemented with different levels of $\mathrm{NaCl}(0 \%, 3 \%, 6 \%, 9 \%$, and $12 \%)$ to assess their ability to mitigate salt stress. For $48 \mathrm{hrs}$, the flasks were incubated at $27^{\circ} \mathrm{C}$ and $120 \mathrm{rpm}$ in a shaking incubator, after which the OD $(600 \mathrm{~nm})$ was determined using a spectrophotometer. For bacterial identification, genomic DNA was extracted from bacterial fluid samples $(200 \mathrm{~mL})$ using a QIAmp DNA Minikit (Qiagen) according to the manufacturer's instructions, and with a final eluted volume of $100 \mu \mathrm{L}$. Extracted DNA was then amplified for PCR, which was performed using $16 \mathrm{~S}$ rRNA gene-specific primers: 27F primer (5'-AGAGTTTGATCACTGGCTCAG$3^{\prime}$ ) and 1492R primer (5'-CGGCTTACCTTGTTACGACTT-3'). PCR amplifications were performed with $1 \times$ Ex Taq buffer (Takara Bio Inc, Japan), 0.8-mM dNTP, 0.02 unit's $_{\mu \mathrm{L}^{-1}}$ of Ex Taq polymerase, $0.4-\mathrm{mg} \mathrm{mL}^{-1}$ bovine serum albumin, and $1.0 \mu \mathrm{M}$ of each primer. The amplifications were also performed at an annealing temperature of $55^{\circ} \mathrm{C}(40 \mathrm{~s})$, an initial denaturation temperature of $94{ }^{\circ} \mathrm{C}$ (5 min), with 30 amplification cycles including denaturation at $94{ }^{\circ} \mathrm{C}(60 \mathrm{~s})$, annealing $(30 \mathrm{~s})$, and extension at $72{ }^{\circ} \mathrm{C}(60 \mathrm{~s})$, and finally the last extension at $72{ }^{\circ} \mathrm{C}(10 \mathrm{~min})$. A Wizard ${ }^{\circledR}$ PCR Preps DNA Purification System was used to purify the PCR product (Promega, Madison, WI, USA). Purified double-stranded PCR fragments were directly sequenced using a Big Dye Terminator Cycle sequencing kit (Applied Biosystems, Forster City, CA, USA) following the manufacturer's instructions. Chromas Lite 2.01 (http:/ / www.technelysium.com.au/chromas.html, 11 June 2020) was used to alter sequences for each zone. For the $16 \mathrm{~S}$ region of bacteria, BLAST (http:/ / www.ncbi.nlm.nih.gov/BLAST, 1 August 2021) was used to compare the sequence homology of nucleotides. To construct a neighboring tree, ClustalW was used to align the sequences along with MEGA (6.0) (Department of Biological Sciences, Tokyo Metropolitan University, Tokyo, Japan). To statistically support the nodes in the phylogenetic trees, bootstrap replication (1000 replications) was also performed.

\subsection{Screening of MAK9 Culture Filtrate for Organic Acid and IAA Production}

The bacterial isolate MAK9 was grown in LB media (10-g tryptone, 5-g yeast extract, and $\mathrm{pH}$ 7.2) for 3 days, after which it was centrifuged (5000 $\times g$ for $10 \mathrm{~min}$ ) and the culture filtrate was analyzed for organic acid and IAA production [30]. For organic acid content analysis, the bacterial culture broth was filtered through a $0.45 \mu \mathrm{m}$ Millipore filter (DISMIC-25CS, ADVANTE, Tokyo, Japan) and $10 \mu \mathrm{L}$ of each sample was injected into a high-performance liquid chromatography (HPLC) column (waters $600 \mathrm{E}$; column: RSpak KC-811 [8.0 $\left.\times 300 \mathrm{~mm}^{2}\right]$; eluent: $0.1 \% \mathrm{H}_{3} \mathrm{PO}_{4} / \mathrm{H}_{2} \mathrm{O}$; flow rate: $1.0 \mathrm{~mL} / \mathrm{min}$; temperature: $40{ }^{\circ} \mathrm{C}$ ). The retention times and peak areas of the chromatograms were compared with standards from Sigma-Aldrich, St. Louis, MO, USA (Table S1). For IAA analysis, the culture filtrates were acidified to a pH of 2.8 and supplemented with $40 \mu \mathrm{L}$ of (D5)-IAA 
as an IAA internal standard. The acidified and standard-supplemented free culture cells were extracted, methylated, and injected into a GC/MS-SIM (6890N network GC system and 5973 network mass selective detector; Agilent Technologies, Santa Clara, CA, USA) to identify and quantify IAA (Table S2).

\subsection{Effects of MAK9 on the Growth Attributes of Chinese Cabbage Plants}

Chinese cabbage plant seeds were surface sterilized with $70 \%$ ethanol for $10 \mathrm{~min}$ and then washed three times with autoclaved distilled water. Petri dishes with two layers of filter paper were autoclaved; Chinese cabbage seeds were kept on wet sterile filter paper and incubated for 3 days at $27^{\circ} \mathrm{C}$ for germination. Uniformly germinated seedlings were transferred to pots $\left(10 \times 9 \mathrm{~cm}^{2}\right)$ containing autoclaved soil. Treatments were as follows: (1) control Chinese cabbage plants provided with autoclaved water, (2) bacteria-inoculated Chinese cabbage plants, (3) plants treated with food waste powder (Seyen Co., Ltd., Kyungsan, Korea) (8\%), and (4) plants treated with food waste powder and inoculated with the isolate MAK9. After being transferred to pots, each plant was supplied with $10 \mathrm{~mL}$ of MAK9 cell suspension. The seedlings were normally lifted for the mutualistic association of bacteria and planted for about 2 weeks in the pots. Food waste was introduced as a treatment after two weeks. Food waste extract solution $(10 \mathrm{~mL} ; 8 \%)$ was applied to the pots every 3 days and this treatment was continued for $\sim 2$ weeks. The growth characteristics of the harvested plants, i.e., fresh and dry weight, root measurements, and shoot length were assessed after 20 days. Chlorophyll content was measured using a SPAD meter (SPAD-502 Minolta, Tokyo, Japan).

\subsection{Estimation of Enzymatic Activities}

To determine catalase (CAT) content, the method of Imran et al. [31] was used; $20 \mathrm{mg}$ of leaves were homogenized in 50-mM Tris-HCl buffer ( $\mathrm{pH} 7.0$ ) containing 1-mM EDTA, 3-mM $\mathrm{MgCl}_{2}$, and 1.0\% PVP and then centrifuged at 15,000 rpm and $22{ }^{\circ} \mathrm{C}$ for $15 \mathrm{~min}$. Subsequently, 10-mM phosphate buffer ( $\mathrm{pH} 7.0$ ) and $0.5 \mathrm{~mL}$ of $0.2-\mathrm{M} \mathrm{H}_{2} \mathrm{O}_{2}$ were added to the supernatant. An absorption decrease occurred at $240 \mathrm{~mm}$ and the activity of the enzyme was determined. One unit of CAT was given as $\mu \mathrm{g}$ of $\mathrm{H}_{2} \mathrm{O}_{2}$ released by $\mathrm{mg}$ of protein min $^{-1}$. To determine peroxidase (POD) content, the established protocol of Kubi et al. [27] was used; the reaction mixture was incubated at $25^{\circ} \mathrm{C}$ for $5 \mathrm{~min}$, and then $5 \% 0.5 \mathrm{~mL} \mathrm{H}_{2} \mathrm{SO}_{4}$ was used to stop the reaction. Absorptive measurements were then taken at $420 \mathrm{~nm}$. The same reaction mixture used for POD was used for polyphenol oxidase (PPO) activity but without $\mathrm{H}_{2} \mathrm{O}_{2}$; the results were also measured at $420 \mathrm{~nm}$. Protein content was estimated using the Bradford assay [32] at an OD of $595 \mathrm{~nm}$. Ascorbic peroxidase (APX) activity was measured following the method of Kim et al. [33]. The plant sample was added to a reaction mixture (50-mM potassium phosphate [pH 7], 0.5-mM ascorbate, 0.1-mM hydrogen peroxide, and 0.1-mM EDTA), and the decrease in absorbance was measured from 10 to $30 \mathrm{~s}$ at $290 \mathrm{~nm}$ using a spectrophotometer. The method of Khan et al. [34] was used to assess superoxide dismutase (SOD) activity. Briefly, leaf samples (100 mg) were homogenized with 0.01-M phosphate buffer at $\mathrm{pH} 7$ and then centrifuged $\left(17,000 \times g\right.$ for $15 \mathrm{~min}$ at $\left.4^{\circ} \mathrm{C}\right)$. The supernatant, which was used as a crude enzyme extract, was passed through a reaction mixture containing Tris- $\mathrm{HCl}$ buffer ( $2 \mathrm{~mL}$; $\mathrm{pH} 8.2)$, double-distilled water ( $2 \mathrm{~mL})$, and 2-mM pyrogallol $(0.5 \mathrm{~mL})$. The absorption of the assay mixture and a blank (lacking pyrogallol or tissue homogenate) was measured at $470 \mathrm{~nm}$ using a spectrophotometer (Multiskan GO; Thermo Fisher Scientific, Waltham, MA, the United States) at $180 \mathrm{~s}$ intervals; data are expressed as units/mg of protein. To determine the reduction in glutathione (GSH) concentration, each sample $(500 \mathrm{mg}$ ) was treated with $2 \mathrm{~mL}$ of $10 \%$ trichloroacetic acid and centrifuged at $10,000 \mathrm{rpm}$ for $15 \mathrm{~min}$ at $4{ }^{\circ} \mathrm{C}$. The resulting supernatant $(1 \mathrm{~mL})$ was combined with $0.5 \mathrm{~mL}$ of Ellman's reagent and $3 \mathrm{~mL}$ of $15-\mathrm{mM}$ sodium phosphate buffer $(\mathrm{pH} \mathrm{7.4)}$ and incubated for $5 \mathrm{~min}$ at $30{ }^{\circ} \mathrm{C}$. Thereafter, the absorbance was measured at $412 \mathrm{~nm}$ using a spectrophotometer. For analysis of superoxide anion production, $1 \mathrm{~g}$ of fresh plant powder sample was immersed in 10-mM sodium phosphate buffer $(\mathrm{pH} 7.0)$ containing $0.05 \%(w / v)$ 
NBT and $10-\mathrm{mM} \mathrm{NaN}_{3}$ for $1 \mathrm{~h}$ at room temperature. Afterwards, $5 \mathrm{~mL}$ of the solution was transferred into a new test tube and heated for $15 \mathrm{~min}$ at $85^{\circ} \mathrm{C}$ in a water bath. Immediately after heating, the solution was cooled down in ice, vacuum filtered, and analyzed at $580 \mathrm{~nm}$ using a spectrometer. Superoxide anion scavenging activity was calculated using the following equation: Scavenging $(\%)=\left(\mathrm{A}_{580}\right.$ Control $-\mathrm{A}_{580}$ Sample $/ \mathrm{A}_{580}$ Control $) \times 100[35,36]$. The experiment was repeated in triplicate.

\subsection{Quantification of Endogenous $A B A$ and $S A$}

For the quantification of endogenous ABA content in the freeze-dried samples, a GC-MS (5973 Network Mass Selective Detector and 6890N Network Gas Chromatograph, Agilent Technologies, Santa Clara, CA, USA) method was used (Table S3). Specifically, LabBase (ThermoQuest, Manchester, UK) data system software was used to monitor responses to ions at $m / z 162$ and 190 for Me-ABA and $m / z 166$ and 194 for Me-[ $\left.{ }^{2} \mathrm{H}_{6}\right]-\mathrm{ABA}$. Analysis of SA was conducted according to the method of Jan et al. [37]; the freeze-dried areal parts of the plants were used for HPLC analysis with a Shimadzu system equipped with a fluorescence detector (RF-10AXL, Shimadzu, Japan), including excitation and emission at 305 and $365 \mathrm{~nm}$, respectively, and fitted with a C18 reverse phase HPLC column (HP Hypersil ODS; particle size: $5 \mu \mathrm{m}$, pore size: 120 A; Waters, MA, USA) (Table S4). Flow rate was maintained at $1 \mathrm{~mL} / \mathrm{min}$.

\subsection{Inductively Coupled Plasma (ICP) Analysis of Ion Uptake}

To determine ionic uptake, the method of Khan et al. [38] was followed using freezedry samples. All samples $(0.2 \mathrm{~g})$ were first digested with $5 \mathrm{~mL}$ of $\mathrm{HNO}_{3}$ and $3 \mathrm{~mL}$ of $\mathrm{H}_{2} \mathrm{O}_{2}$ in a microwave, and then $3 \% \mathrm{HNO}_{3}$ was added to further digest the samples. For the quantification of calcium $(\mathrm{Ca})$, sodium $\left(\mathrm{Na}^{+}\right)$, and potassium $\left(\mathrm{K}^{+}\right)$content, samples were injected through an ICP mass spectrometry system.

\section{Analysis of Sugars}

The sugar content (glucose, fructose, and sucrose) in freeze-dried powder (0.5 g) from shoots was solubilized using $80 \%$ ethanol and kept for $24 \mathrm{~h}$ at room temperature. Samples were then placed in a water bath at $80^{\circ} \mathrm{C}$ for $30 \mathrm{~min}$, after which they were cooled, centrifuged, and the extract was then dried using a vacuum dryer. The dried residue was redissolved in $2 \mathrm{~mL}$ of deionized water and then passed through $0.45-\mu \mathrm{m}$ Nylon-66 syringe filters. Subsequently, the filtrated samples were injected into a HPLC Waters system (Millipore Corp., Waters Chromatography, Milford, MA, USA) comprising a Sugar-Pak column (300 mm; a model 60 controller) and sugar signals were detected using a Waters 410 refractive index detector (Table S5). Sucrose, fructose, and glucose were quantified by comparing their peaks area with those of specific standards.

\section{Statistical Analysis}

Data were statistically analyzed using Duncan's multiple range test in Statistical Analysis Software (SAS: V 9.2, Institute Inc, Cary, NC, USA). Unless otherwise stated, the experiments were repeated twice with 15 replicates per treatment and data collected from each replicate were pooled. GraphPad Prism (version 6.01; San Diego, CA, USA) was used to create graphical presentations.

\section{Results}

\subsection{Isolation, Screening, and Identification}

In total, 27 isolates were isolated and these were screened for plant growth-promoting traits (siderophore, phosphate, IAA, and EPS production). Based on the screening results, $16,10,12$, and 12 isolates were positive for IAA production, siderophore activity, EPS production, and phosphate solubilization, respectively (Figure S1). Isolate MAK9 showed high tolerance to salt stress (Figure S2) and was, therefore, further investigated for molecular 
identification. Analysis showed that isolate MAK9 shared sequence identity with Bacillus pumilus; it was submitted to NCBI with the accession number MZ675645 (Figure 1).

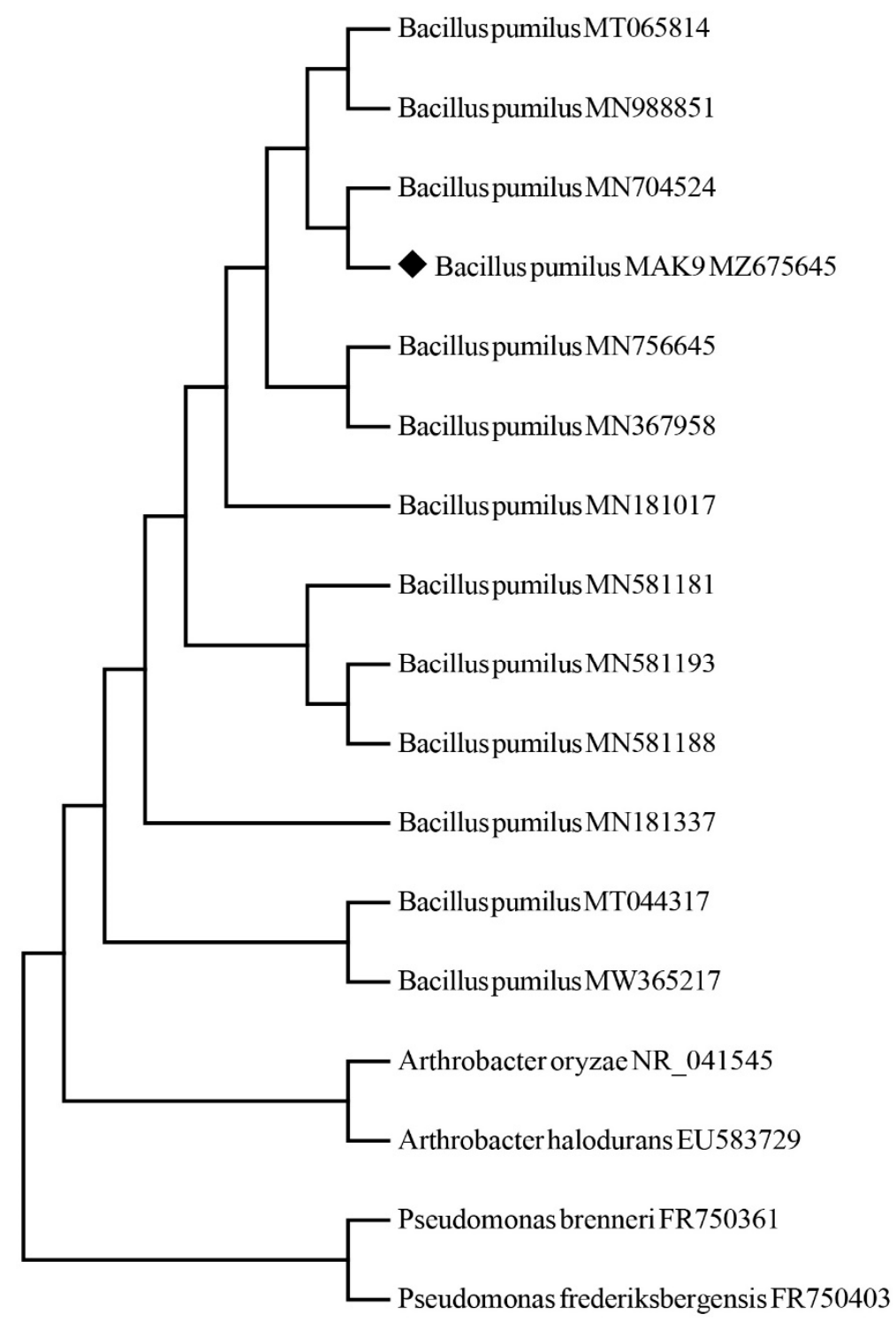

Figure 1. Phylogenetic tree of isolate MAK9 constructed using $16 \mathrm{~S}$ rRNA sequences as well as neighbor-joining and maximum-likelihood methods. $\downarrow$ represents the bacterial strain.

\subsection{In Vitro IAA and Organic Acid Production of Isolate MAK9}

Isolate MAK9 was grown in LB media for 5 days, centrifuged, and the culture filtrate was tested for IAA and organic acid production (Figure 2). MAK 9 produced IAA (Figure 2A) as well as acetic acid, succinic acid, and lactic acid. Moreover, the highest amount of acetic acid was observed in the culture filtrate of isolate MAK9 (Figure 2B). 

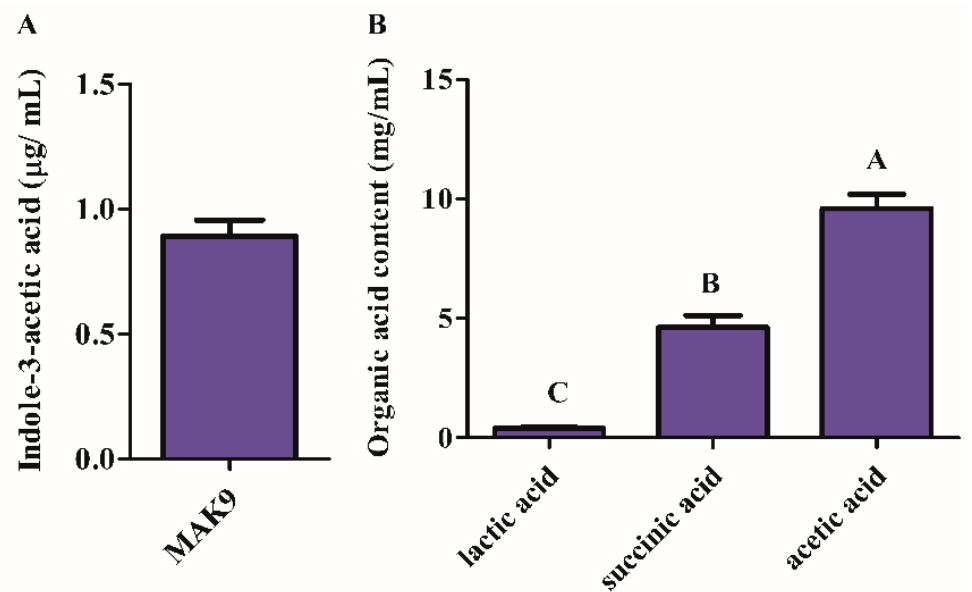

Figure 2. Quantification of indole-3-acetic acid (IAA) and organic acids produced by isolate MAK9. (A) GC/MS-SIM analysis of the IAA content in the culture broth of isolate MAK9. (B) Organic acids were detected and quantified using high-performance liquid chromatography relative to their respective standards. Different letters indicate significant differences between the mean values of three replicates \pm standard deviation.

\subsection{Bacterial Isolates Regulate Chinese Cabbage Growth under Food Waste}

The application of food waste $(8 \%)$ was found to reduce the growth attributes of Chinese cabbage plants (Figure 3): shoot length $(9.16 \pm 0.70)$, root length $(5.5 \pm 0.5)$, fresh weight $(1.8 \pm 0.05)$, dry weight $(0.14 \pm 0.05)$, and chlorophyll content $(21.6 \pm 1.6)$ were decreased in Chinese cabbage plants treated with $8 \%$ food waste compared with the shoot length $(17.20 \pm 1.0)$, root length $(12.0 \pm 1.0)$, fresh weight $(2.6 \pm 0.1)$, dry weight $(0.22 \pm 0.05)$, and chlorophyll content $(27.1 \pm 1.1)$ of control plants (Table 1$)$. However, microbe inoculation inhibited the effect of salt stress caused by food waste; it increased shoot length $(12.1 \pm 0.7)$, root length $(7.8 \pm 0.7)$, fresh weight $(2.1 \pm 0.05)$, dry weight $(0.19 \pm 0.05)$, and chlorophyll content $(24.5 \pm 0.7)$ in plants treated with food waste and bacterial inoculation compared with those treated with food waste alone (Table 1).

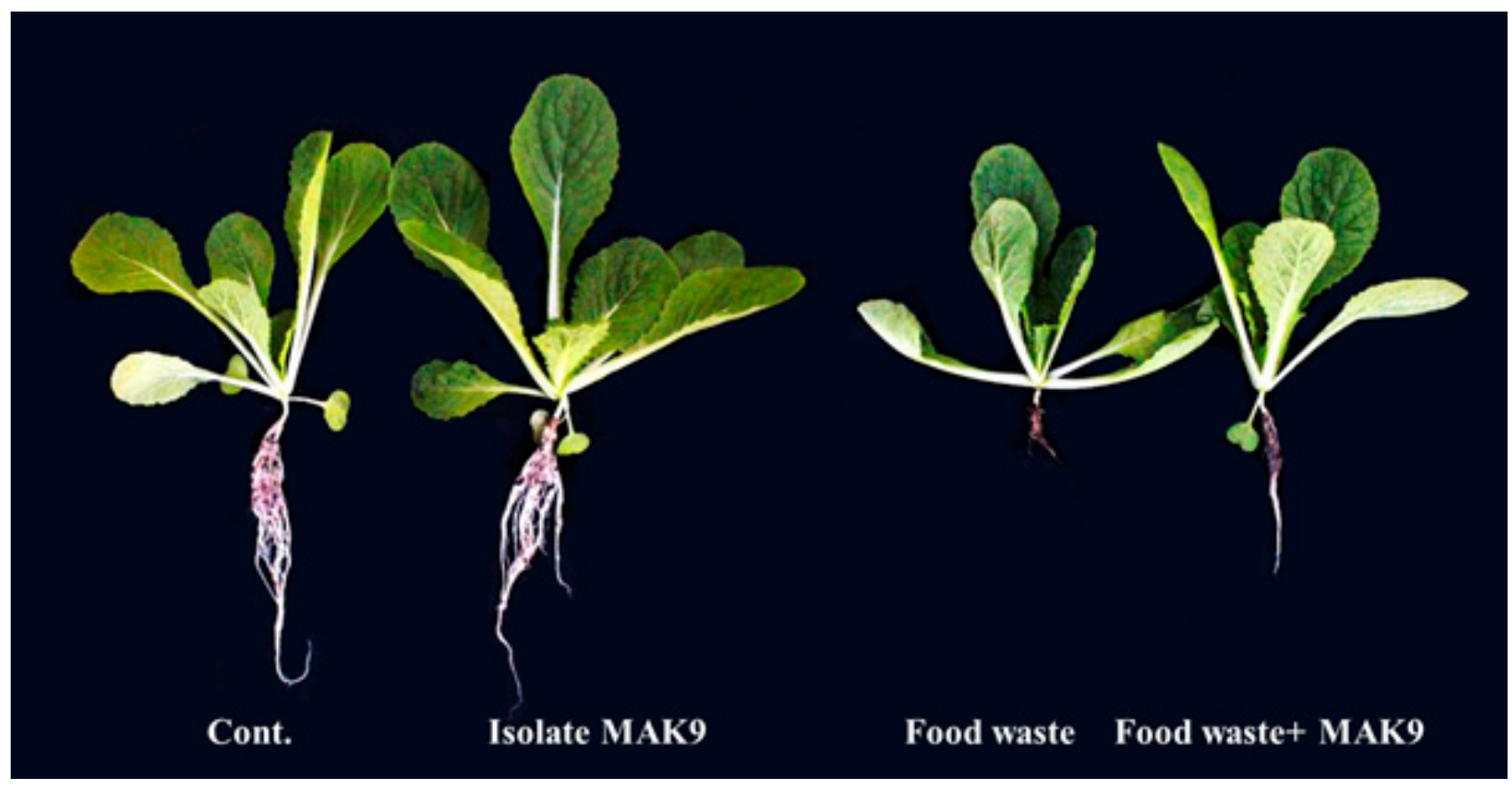

Figure 3. Effects of bacterial isolate MAK9 on the growth of Chinese cabbage and on the effects of food waste $(8 \%)$ application. 
Table 1. Effect of Bacillus pumilus MAK9 on the growth attributes of Chinese cabbage.

\begin{tabular}{cccccc}
\hline & RL $(\mathbf{c m})$ & SL $(\mathbf{c m})$ & FW (g/Three Plants) & DW (g/Three Plants) & CC (SPAD) \\
\hline Control & $12.0 \pm 1.00^{\mathrm{B}}$ & $17.20 \pm 1.00^{\mathrm{B}}$ & $2.66 \pm 0.11^{\mathrm{B}}$ & $0.22 \pm 0.005^{\mathrm{B}}$ & $27.10 \pm 1.13^{\mathrm{B}}$ \\
MAK9 & $15.33 \pm 0.57^{\mathrm{A}}$ & $19.33 \pm 0.57^{\mathrm{A}}$ & $3.22 \pm 0.10^{\mathrm{A}}$ & $0.29 \pm 0.005^{\mathrm{A}}$ & $30.10 \pm 2.54^{\mathrm{A}}$ \\
Food waste (8\%) & $5.50 \pm 0.50^{\mathrm{D}}$ & $9.16 \pm 0.76^{\mathrm{D}}$ & $1.83 \pm 0.05^{\mathrm{C}}$ & $0.14 \pm 0.005^{\mathrm{D}}$ & $21.60 \pm 1.69^{\mathrm{D}}$ \\
MAK9 + food & $7.80 \pm 0.76^{\mathrm{C}}$ & $12.16 \pm 0.76^{\mathrm{C}}$ & $2.16 \pm 0.05^{\mathrm{B}}$ & $0.19 \pm 0.005^{\mathrm{C}}$ & $24.50 \pm 0.70^{\mathrm{C}}$ \\
waste (8\%) & & & & & \\
\hline
\end{tabular}

RL, root length; SL, shoot length; FW, fresh weight; DW, dry weight; and CC, chlorophyll content. Values are means \pm standard deviation of three replicates. Comparisons were conducted using Duncan's multiple range test with significance at $p>0.05$. Different letters in columns indicate differences among treatments.

\subsection{Effect of Food Waste on $A B A$ and SA Content}

Chinese cabbage plants treated with food waste or with food waste and bacterial inoculation were also tested to quantify endogenous SA and ABA content. The salt content in food waste significantly increased ABA content (3-fold); however, Chinese cabbage plants also inoculated with isolate MAK9 showed a significant decrease in ABA content (2-fold) compared with those treated with food waste alone (Figure 4A). In contrast, endogenous SA content decreased in food waste-treated plants; however, bacterial inoculated Chinese cabbage plants showed an increase in SA content $(11 \%)$ compared with that in plants treated only with food waste (Figure 4B).
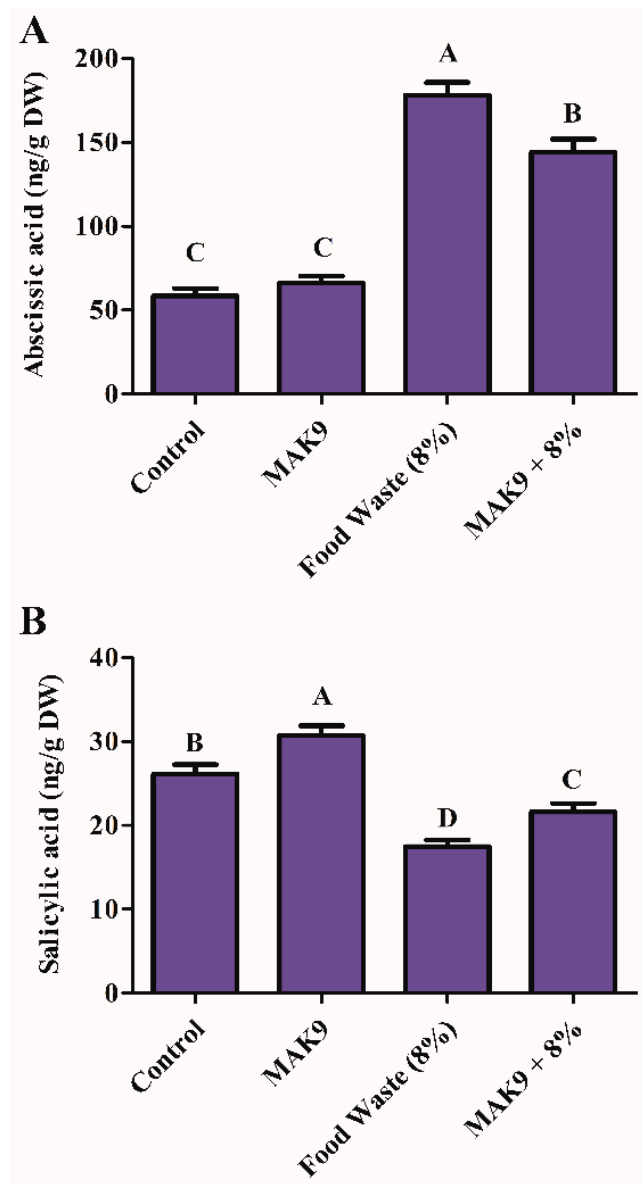

Figure 4. Endogenous abscisic acid (A) and salicylic acid (B) content in Chinese cabbage after food waste $(8 \%)$ treatment and/or inoculation with isolate MAK9. Different letters indicate differences between the mean values of three replicates \pm standard deviation. 


\subsection{Quantification of Antioxidants in Chinese Cabbage under Food Waste Treatments}

To investigate the influence of food waste on the antioxidant defense system of Chinese cabbage, the activities of major ROS scavenging enzymes, i.e., CAT, POD, PPO, GSH, and SOD, were investigated. No differences in antioxidant regulation were found between bacterial inoculated Chinese cabbage and the control plants. However, increases in CAT (26\%), POD (1-fold), GSH (40\%), PPO (66\%), and SOA (67\%) were observed in food waste-treated plants compared with control plants, whereas a decrease in total protein content $(36 \%)$ was detected in treated plants (Figure 5). However, Chinese cabbage plants inoculated with isolate MAK9 showed a decrease in GSH (11\%), PPO (17\%), and SOA (18\%) levels compared with those observed in food waste-treated plants. Moreover, increases in CAT $(14 \%)$, POD $(19 \%)$, and total protein content $(26.96 \%)$ were observed in food wastetreated Chinese cabbage plants that were also inoculated with isolate MAK9 (Figure 5F).
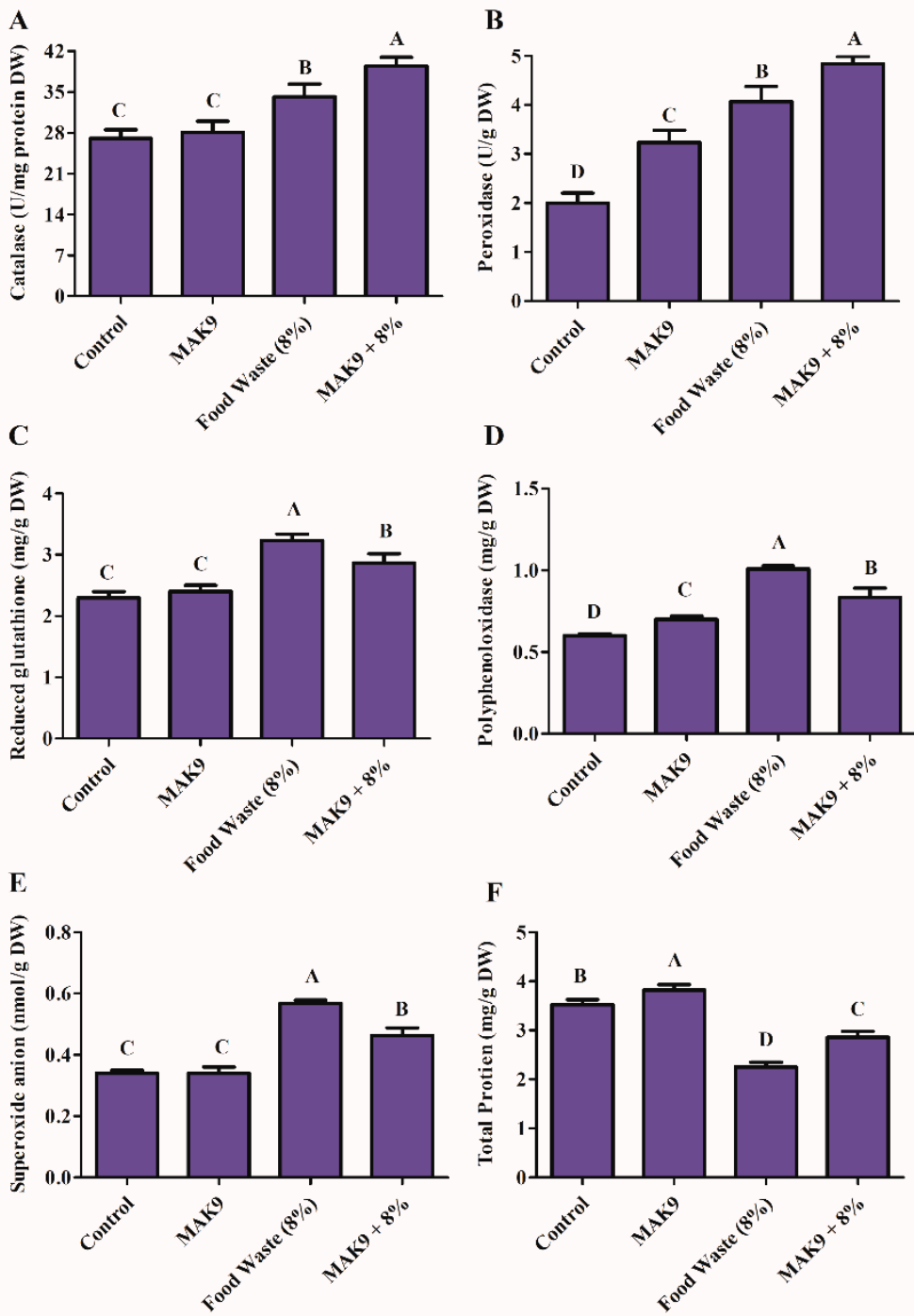

Figure 5. Effects of isolate MAK9 on antioxidant levels in Chinese cabbage with and without food waste (8\%) application. (A) Catalase, (B) peroxidase, (C) glutathione, (D) polyphenol oxidase, (E) superoxide anions, and (F) total protein. Different letters indicate differences between the mean values of three replicates \pm standard deviations.

\subsection{ICP Analysis of $\mathrm{Na}, \mathrm{K}, \mathrm{P}$, and $\mathrm{Ca}$ Content}

The accumulation of $\mathrm{Ca}, \mathrm{Na}, \mathrm{K}$, and $\mathrm{P}$ were investigated using ICP analysis in control and food waste-treated Chinese cabbage with and without isolate MAK9 inoculation (Figure 6). Decreases in Ca $(11.34 \mathrm{mg} / \mathrm{kg}), \mathrm{K}(26.42 \mathrm{mg} / \mathrm{kg})$, and P $(49.82 \mathrm{mg} / \mathrm{kg})$ content 
were observed in food waste-treated Chinese cabbage plants compared with in control plants (Ca, $12.40 \mathrm{mg} / \mathrm{kg}$; K, $32.88 \mathrm{mg} / \mathrm{kg}$; and P, $51.79 \mathrm{mg} / \mathrm{kg}$; Figure 6). However, inoculation with isolate MAK9 mitigated the inhibitory effect of food waste containing salt and enhanced the content of Ca $(11.70 \mathrm{mg} / \mathrm{kg}), \mathrm{K}(32.44 \mathrm{mg} / \mathrm{kg})$, and P $(57.52 \mathrm{mg} / \mathrm{kg})$ in Chinese cabbage plants compared with the respective contents in food waste-treated plants. Conversely, a decrease in Na content $(28.30 \mathrm{mg} / \mathrm{kg})$ was observed in inoculated plants compared with those treated with food waste only $(30.41 \mathrm{mg} / \mathrm{kg}$ ) (Figure 6).

A

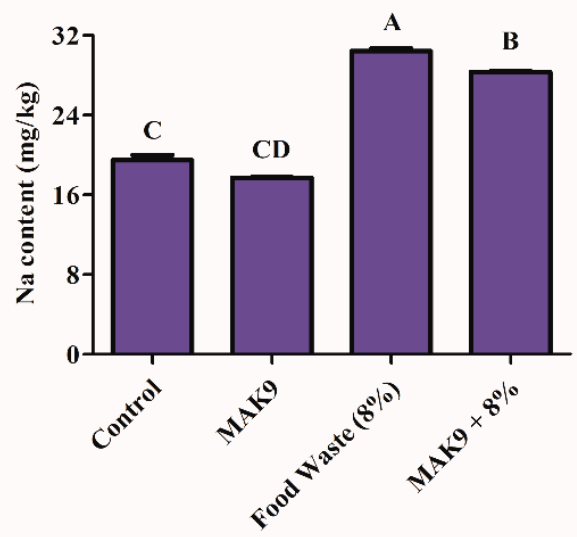

C

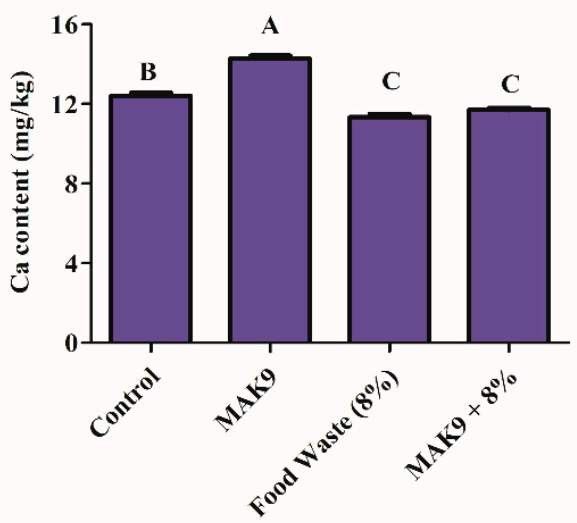

B

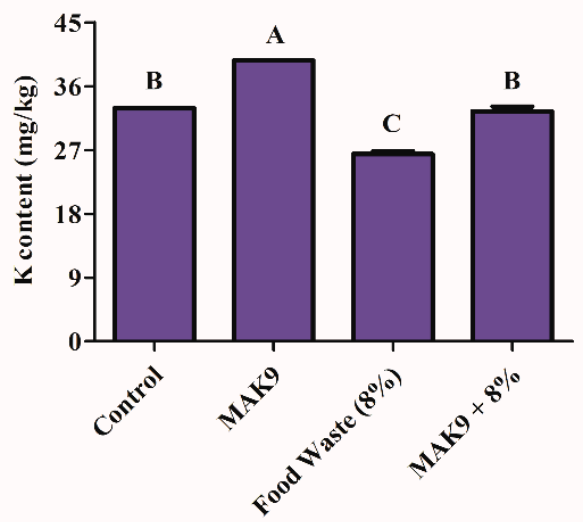

D

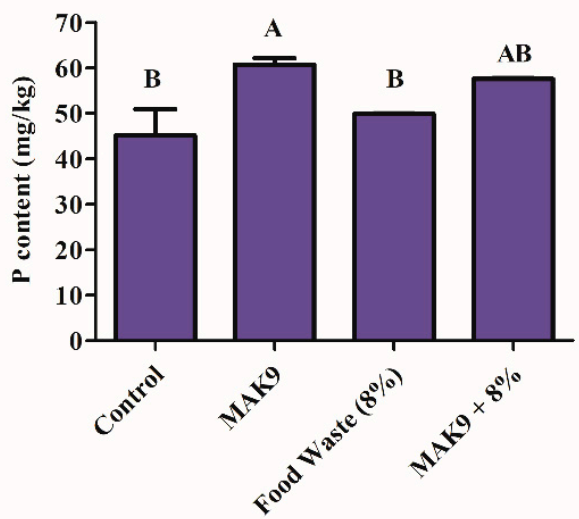

Figure 6. The effect of isolate MAK9 on the sodium ( $\mathrm{Na},(\mathbf{A}))$; potassium $(\mathrm{K},(\mathbf{B}))$; calcium $(\mathrm{C},(\mathbf{C}))$; and phosphorus $(\mathrm{P},(\mathrm{D}))$ content of Chinese cabbage inoculated with isolate MAK9 and/or treated with food waste ( $8 \%)$. Different letters indicate differences between the mean values of three replicates \pm standard deviations.

\subsection{Sugar Content Analysis}

The effects of food waste treatment and bacterial inoculation on Chinese cabbage plants' sugar metabolism were evaluated by quantifying sucrose, glucose, and fructose content (Table 2). Decreases in glucose $(26 \%)$, fructose $(20 \%)$, and sucrose $(16 \%)$ content were observed in food waste-treated Chinese cabbage plants compared with in control plants (Table 2). However, inoculation with isolate MAK9 apparently inhibited the effect of salt present in food waste and thereby enhanced the content of glucose $(17 \%)$, fructose $(11 \%)$, and sucrose $(14 \%)$ in Chinese cabbage plants (Table 2). 
Table 2. Effects of Bacillus pumilus MAK9 on the total sugar content (glucose, fructose, and sucrose) of Chinese cabbage plants when administered with and without food waste treatment.

\begin{tabular}{cccc}
\hline & Glucose & Fructose & Sucrose \\
\hline Control & $8.80 \pm 0.20^{\mathrm{A}}$ & $5.70 \pm 0.30^{\mathrm{A}}$ & $1.21 \pm 0.10^{\mathrm{A}}$ \\
MAK9 & $8.89 \pm 0.20^{\mathrm{A}}$ & $5.89 \pm 0.40^{\mathrm{A}}$ & $1.32 \pm 0.10^{\mathrm{A}}$ \\
Food waste $(8 \%)$ & $6.45 \pm 0.22^{\mathrm{C}}$ & $4.51 \pm 0.27^{\mathrm{B}}$ & $1.01 \pm 0.10^{\mathrm{B}}$ \\
MAK9 + food waste $(8 \%)$ & $7.55 \pm 0.25^{\mathrm{B}}$ & $5.02 \pm 0.20^{\mathrm{B}}$ & $1.16 \pm 0.03^{\mathrm{AB}}$ \\
\hline
\end{tabular}

Values are means \pm standard deviations of three replicates. Comparisons were made using Duncan's multiple range test with significance at $p>0.05$. Different letter in columns indicate differences among treatments.

\section{Discussion}

Food waste-based compost provides organic matter to the soil that can substantially improve soil properties [39]. However, the major impediment to the use of food wastebased compost in agriculture is the risk of increasing salinity caused by the salt in the waste, which affects stabilization and lowers the efficiency of solid degradation during the composting process. For sustainable crop cultivation, the law indicates that $\mathrm{NaCl}$ content in food waste compost must be $<2 \%$ [19]. Lee et al. [20] reported that the average salt content in 290 food waste samples collected from all over Korea was 2.03\%. The inhibitory effect of salinity stress is largely due to ionic, osmotic, and oxidative stresses, which limit plant growth and reduce yield in crops $[40,41]$. Salinity stress influences some basic metabolic process in plants including photosynthesis, biosynthesis, lipid metabolism, and protein synthesis [40,42]. Moreover, increase in photosynthetic rate can ameliorate the harmful effects of salt stress and help maintain normal plant growth and development. In the current study, $\mathrm{NaCl}$ content in food waste negatively affected the growth attributes and chlorophyll content of Chinese cabbage (Figure 3; Table 1), similar to previous reports for soybean, maize, pepper, tomato, and cucumber under salinity stress [25-27,43-45]. Similarly, several halotolerant plant growth promoting bacterial inocula have been reported to alleviate salt stress and enhance plant growth in different crops, such as wheat, goat's rue, rice, cotton, tomato, and pepper [46-49], that support our current results in isolate MAK9 inoculated Chinese cabbage treated with food waste (Figure 3; Table 1).

The plant cell membrane plays an important role in the maintenance of the cell microenvironment and metabolism. However, $\mathrm{NaCl}$ stress reduces the permeability of the cell membrane through $\mathrm{Na}$ accumulation, which competes with the binding sites of $\mathrm{K}$ by reducing the K outflow that inactivates enzymatic and metabolic plant processes [50,51]. Na shares an antagonistic relationship with K, which was confirmed by our finding that K uptake was reduced in food waste-treated Chinese cabbage (Figure 6A,B), similar to salinity induced reductions in K uptake previously reported in tomato [52] and lettuce [53] plants. High concentrations of $\mathrm{Na}$ in cellular tissues hamper various growth and metabolic process in plants [54]. Here, Na content was higher in food waste-treated plants, but bacterial inoculation reduced this $\mathrm{Na}$ content (Figure 6A). It is known that lowered Ca levels under salt stress can affect the ion balance of the cytoplasmic membrane. In the current study, Chinese cabbage maintained higher Ca content with bacterial inoculation of isolate MAK9 alongside food waste treatment compared with food waste treatment alone (Figure 6C). $\mathrm{P}$ is also an essential nutrient that is required for various metabolic processes including photosynthesis, energy transfer, and signal transduction; consequently, P deficiency limits plant growth [55]. Our ICP results showed that Chinese cabbage inoculated with bacteria had higher P content than plants that were not inoculated (Figure 6D). Similarly, previous studies on bacteria-inoculated tomato and mung bean plants showed the positive influence of bacteria on the growth of salinity stressed plants via improved P uptake [56,57].

Most of the soluble sugar in plants comes from the photosynthate of sucrose in leaves, which can be decomposed into fructose and glucose in sink cells [58,59]. Glucose, fructose, and sucrose are readily accessible and provide osmoprotection and radical scavenging under stress conditions. A previous study showed that salinity stress decreases total soluble sugar content in cucumber plants [60]. In Chinese cabbage, administering bacterial 
inoculation of MAK9 with food waste treatment significantly reduced the negative impact of salt stress by increasing total soluble sugar content (Table 2). Salt content in food waste likely suppresses Chinese cabbage growth by damaging thylakoid membranes, which, in turn, reduce chlorophyll content and affect photosynthetic efficiency, which ultimately leads to reduced production of soluble sugars. Enhanced synthesis of soluble sugars and polysaccharides has previously been found to impart stress tolerance to plants [61]. Our finding of increased soluble sugar content under salinity stress was similar to that reported for tomato [62], wheat [63], cucumber [60], cotton [64], rice [65], and date palm [66] plants.

Phytohormones play important roles in the physiological responses and adaptation of plants to abiotic stresses such as salinity [67]. Among the phytohormones, ABA is a key mediator of osmotic stress responses; it regulates transpiration rate, controls stomatal opening, induces osmoprotactant accumulation, and activates ROS detoxification [68]. In the current study, the endogenous ABA levels of Chinese cabbage were significantly reduced by MAK9 inoculation alongside food waste treatment when compared with the levels detected with food waste treatment alone (Figure 4A). The decrease in ABA content in bacteria-inoculated plants is supported by previous findings for soybean [25], rice [65], and cucumber [45] plants. SA is also known to play a key role in modulating plant responses to a wide range of oxidative stresses [69]; it acts as a scavenger of ROS and induces systemic resistance that enhances stress tolerance [60]. Here, SA content was increased in food waste-treated plants that were also inoculated with isolate MAK9 (Figure 4B).

Higher reactive oxygen levels are produced during stress conditions, which lead to oxidative damage to proteins, lipids, and the plasma membrane [70]. With higher ROS production, plants produce several antioxidant enzymes to maintain the ROS balance in cells under stress conditions $[70,71]$. Our results showed that salinity stress from food waste increased the activity of antioxidant enzymes such as SOD, POD, and CAT in bacteria-inoculated Chinese cabbage plants (Figure 5). Similar results have been reported for desert bunchgrass [54] and alfalfa [72]. SOD is considered the first defensive enzyme as it scavenges superoxide radicals to hydrogen peroxide, which is further detoxified to water; furthermore, POD and CAT convert $\mathrm{H}_{2} \mathrm{O}_{2}$ to $\mathrm{H}_{2} \mathrm{O}$. In a study of maize plants [27], higher antioxidant activities (including for SOD) were detected in bacteria-inoculated plants compared with those subjected to salt stress. Similarly, increased CAT activities were observed in soybean and rice plants inoculated with halotolerant bacteria under salinity stress. PPO, the enzyme that catalyzes the oxidation of phenolic compounds into highly reactive quinines, is also induced by salinity stress [72]. We found higher PPO content in bacteria-inoculated plants than that in control plants (Figure 5); thus, elevated PPO activity may reflect an increase in ROS scavenging capacity aimed at protecting plants from salinity stress.

\section{Conclusions}

Our results show that food waste can have detrimental effects on the physiological and biochemical parameters of Chinese cabbage due to the presence of high salt content. However, inoculation with isolate MAK9 in addition to food waste treatment was shown to enhance Chinese cabbage growth, reduce $\mathrm{NaCl}$ toxicity, inhibit $\mathrm{Na}^{+}$uptake, and have positive antioxidant effects. These findings demonstrate that isolate MAK9 can alleviate salinity stress; therefore, it represents a valuable ecofriendly microorganism resource and a low-cost biotechnological approach to providing sustainable agriculture. It remains necessary to determine the specific application dose of food waste that avoids the negative impact of salinity in crop plants. Furthermore, long term evaluation of treatment with food waste plus halotolerant microbes is required with evaluation of soil quality parameters and plant growth under field conditions. 
Supplementary Materials: The following are available online at https:/ / www.mdpi.com/article/10 .3390 /horticulturae8010049/s1, Figure S1: Screening of bacterial isolates for different plant growthpromoting activities, Figure S2: Multiple plant growth-promoting traits produced by rhizospheric bacteria, Table S1: HPLC conditions used for analysis and quantification of organic acids, Table S2: GC/MS-SIM conditions used for analysis and quantification of IAA, Table S3: GC/MS-SIM conditions used for analysis and quantification of ABA, Table S4: HPLC conditions used for analysis and quantification of SA, Table S5: HPLC conditions used for the analysis and quantification of sugar content.

Author Contributions: Conceptualization and methodology, M.A.K. and I.-J.L.; software, K. and L.; formal analysis, M.I., S.S., E.-H.K. and S.-M.K.; resources, S.-H.K.; M.A.K.; writing-original draft preparation, M.A.K.; writing-review and editing, M.H.; supervision, I.-J.L.; funding acquisition, I.-J.L. All authors have read and agreed to the published version of the manuscript.

Funding: This study was supported by the Agenda Program (Project No. PJ015163032021) Rural Development Administration, Korea.

Institutional Review Board Statement: Not applicable.

Informed Consent Statement: Not applicable.

Conflicts of Interest: The author declares no conflict of interest.

\section{References}

1. Bratovcic, A.; Zohorović, M.; Odobasic, A.; Šestan, I. Efficiency of food waste as an organic fertilizer. Int. J. Eng. Sci. Res. Technol. 2018, 7, 527-530. [CrossRef]

2. FAO. Global food losses and food waste-Extent, causes and prevention. In SAVE FOOD: An Initiative on Food Loss and Waste Reduction; FAO: Rome, Italy, 2011.

3. Schanes, K.; Dobernig, K.; Gözet, B. Food waste matters-A systematic review of household food waste practices and their policy implications. J. Clean. Prod. 2018, 182, 978-991. [CrossRef]

4. $\quad$ Paritosh, K.; Kushwaha, S.K.; Yadav, M.; Pareek, N.; Chawade, A.; Vivekanand, V. Food Waste to Energy: An Overview of Sustainable Approaches for Food Waste Management and Nutrient Recycling. BioMed Res. Int. 2017, 2017, 2370927. [CrossRef]

5. FAO. Towards the Future We Want: End Hunger and Make the Transition to Sustainable Agricultural and Food Systems; Food and Agriculture Organization of the United Nations: Rome, Italy, 2012; pp. 1-42.

6. Kumar, K.; Yadav, A.N.; Kumar, V.; Vyas, P.; Dhaliwal, H.S. Food waste: A potential bioresource for extraction of nutraceuticals and bioactive compounds. Bioresour. Bioprocess. 2017, 4, 18. [CrossRef]

7. Melikoglu, M.; Lin, C.S.K.; Webb, C. Analysing global food waste problem: Pinpointing the facts and estimating the energy content. Cent. Eur. J. Eng. 2013, 3, 157-164. [CrossRef]

8. Kawashima, T. The use of food waste as a protein source for animal feed-Current status and technological development in Japan. In Proceedings of the FAO Animal Production and Health Proceedings (FAO), Protein Sources for the Animal Feed Industry, Expert Consultation and Workshop, Bangkok, Thailand, 29 April-3 May 2002; pp. 303-311.

9. Kim, J.D.; Park, J.S.; In, B.H.; Kim, D.; Namkoong, W. Evaluation of pilot-scale in-vessel composting for food waste treatment. J. Hazard. Mater. 2008, 154, 272-277. [CrossRef]

10. Hamid, H.A.; Qi, L.P.; Harun, H.; Sunar, N.M.; Ahmad, F.H.; Muhamad, M.S. Development of Organic Fertilizer from Food Waste by Composting in UTHM Campus Pagoh. J. Des. Sustain. Environ. 2019, 1, 1-6.

11. Tiwari, A.; Khawas, R. Food Waste and Agro By-Products: A Step towards Food Sustainability; IntechOpen: London, UK, 2021.

12. Hossain, M.Z.; Von Fragstein, P.; Von Niemsdorff, P.; Heß, J. Effect of different organic wastes on soil properties and plant growth and yield: A review. Sci. Agric. Bohem. 2017, 48, 224-237.

13. Zhang, R.; El-Mashad, H.M.; Hartman, K.; Wang, F.; Liu, G.; Choate, C.; Gamble, P. Characterization of food waste as feedstock for anaerobic digestion. Bioresour. Technol. 2007, 98, 929-935. [CrossRef]

14. Mahmood, A.; Iguchi, R.; Kataoka, R. Multifunctional food waste fertilizer having the capability of Fusarium-growth inhibition and phosphate solubility: A new horizon of food waste recycle using microorganisms. Waste Manag. 2019, 94, 77-84. [CrossRef]

15. Kim, J.K.; Oh, B.R.; Chun, Y.N.; Kim, S.W. Effects of temperature and hydraulic retention time on anaerobic digestion of food waste. J. Biosci. Bioeng. 2006, 102, 328-332. [CrossRef]

16. Kang, S.-M.; Shaffique, S.; Kim, L.-R.; Kwon, E.-H.; Kim, S.-H.; Lee, Y.-H.; Kalsoom, K.; Aaqil Khan, M.; Lee, I.-J. Effects of Organic Fertilizer Mixed with Food Waste Dry Powder on the Growth of Chinese Cabbage Seedlings. Environments 2021, 8, 86. [CrossRef]

17. FAO. The Future of Food and Agriculture_Trends and Challenges; Annual Report; FAO: Rome, Italy, $2017 ;$ Volume 296.

18. Lin, C.S.K.; Pfaltzgraff, L.A.; Herrero-Davila, L.; Mubofu, E.B.; Abderrahim, S.; Clark, J.H.; Koutinas, A.A.; Kopsahelis, N.; Stamatelatou, K.; Dickson, F. Food waste as a valuable resource for the production of chemicals, materials and fuels. Current situation and global perspective. Energy Environ. Sci. 2013, 6, 426-464. [CrossRef] 
19. Lee, C.H.; Park, S.J.; Hwang, H.Y.; Kim, M.S.; Jung, H.i.; Luyima, D.; Hong, S.Y.; Oh, T.K.; Kim, S.H. Effects of food waste compost on the shift of microbial community in water saturated and unsaturated soil condition. Appl. Biol. Chem. 2019, 62, 36. [CrossRef]

20. Lee, J.-H.; Kang, Y.-G.; Luyima, D.; Park, S.-J.; Oh, T.-K.; Lee, C.H. Characteristics of food waste: Water and salinity contents. Korean J. Agric. Sci. 2020, 47, 375-380.

21. Shrivastava, P.; Kumar, R. Soil salinity: A serious environmental issue and plant growth promoting bacteria as one of the tools for its alleviation. Saudi J. Biol. Sci. 2015, 22, 123-131. [CrossRef]

22. Machado, R.M.A.; Serralheiro, R.P. Soil Salinity: Effect on Vegetable Crop Growth. Management Practices to Prevent and Mitigate Soil Salinization. Horticulturae 2017, 3, 30. [CrossRef]

23. Tartoura, K.A.H.; Youssef, S.A.; Tartoura, E.-S.A.A. Compost alleviates the negative effects of salinity via up-regulation of antioxidants in Solanum lycopersicum L. plants. Plant Growth Regul. 2014, 74, 299-310. [CrossRef]

24. Adhikari, A.; Khan, M.A.; Lee, K.E.; Kang, S.M.; Dhungana, S.K.; Bhusal, N.; Lee, I.J. The Halotolerant RhizobacteriumPseudomonas koreensis MU2 Enhances Inorganic Silicon and Phosphorus Use Efficiency and Augments Salt Stress Tolerance in Soybean (Glycine max L.). Microorganisms 2020, 8, 1256. [CrossRef] [PubMed]

25. Lubna; Asaf, S.; Hamayun, M.; Khan, A.L.; Waqas, M.; Khan, M.A.; Jan, R.; Lee, I.-J.; Hussain, A. Salt tolerance of Glycine max L. induced by endophytic fungus Aspergillus flavus CSH1, via regulating its endogenous hormones and antioxidative system. Plant Physiol. Biochem. 2018, 128, 13-23. [CrossRef]

26. Kang, S.-M.; Shahzad, R.; Bilal, S.; Khan, A.L.; Park, Y.-G.; Lee, K.-E.; Asaf, S.; Khan, M.A.; Lee, I.-J. Indole-3-acetic-acid and ACC deaminase producing Leclercia adecarboxylata MO1 improves Solanum lycopersicum L. growth and salinity stress tolerance by endogenous secondary metabolites regulation. BMC Microbiol. 2019, 19, 80. [CrossRef]

27. Kubi, H.A.A.; Khan, M.A.; Adhikari, A.; Imran, M.; Kang, S.-M.; Hamayun, M.; Lee, I.-J. Silicon and Plant Growth-Promoting Rhizobacteria Pseudomonas psychrotolerans CS51 Mitigates Salt Stress in Zea mays L. Agriculture 2021, 11, 272. [CrossRef]

28. Chadha, N.; Prasad, R.; Varma, A. Plant Promoting Activities of Fungal Endophytes Associated with Tomato Roots from Central Himalaya, India and Their Interaction with Piriformospora Indica. Int. J. Pharma Bio Sci. 2015, 6, 333-343.

29. Yu-Na, K.; Muhammad Aaqil, K.; Sang-Mo, K.; Muhammad, H.; In-Jung, L. Enhancement of Drought-Stress Tolerance of Brassica oleracea var. italica L. by Newly Isolated Variovorax sp. YNA59. J. Microbiol. Biotechnol. 2020, 30, 1500-1509. [CrossRef]

30. Khan, M.A.; Hamayun, M.; Asaf, S.; Khan, M.; Yun, B.-W.; Kang, S.-M.; Lee, I.-J. Rhizospheric Bacillus spp. Rescues Plant Growth Under Salinity Stress via Regulating Gene Expression, Endogenous Hormones, and Antioxidant System of Oryza sativa L. Front. Plant Sci. 2021, 12, 1145. [CrossRef]

31. Imran, M.; Aaqil Khan, M.; Shahzad, R.; Bilal, S.; Khan, M.; Yun, B.-W.; Khan, A.L.; Lee, I.-J. Melatonin Ameliorates Thermotolerance in Soybean Seedling through Balancing Redox Homeostasis and Modulating Antioxidant Defense, Phytohormones and Polyamines Biosynthesis. Molecules 2021, 26, 5116. [CrossRef]

32. Bradford, M.M. A rapid and sensitive method for the quantitation of microgram quantities of protein utilizing the principle of protein-dye binding. Anal. Biochem. 1976, 72, 248-254. [CrossRef]

33. Kim, Y.; Mun, B.-G.; Khan, A.L.; Waqas, M.; Kim, H.-H.; Shahzad, R.; Imran, M.; Yun, B.-W.; Lee, I.-J. Regulation of reactive oxygen and nitrogen species by salicylic acid in rice plants under salinity stress conditions. PLoS ONE 2018, 13, e0192650. [CrossRef] [PubMed]

34. Khan, M.A.; Ullah, I.; Waqas, M.; Hamayun, M.; Khan, A.L.; Asaf, S.; Kang, S.-M.; Kim, K.-M.; Jan, R.; Lee, I.-J. Halo-tolerant rhizospheric Arthrobacter woluwensis AK1 mitigates salt stress and induces physio-hormonal changes and expression of GmST1 and GmLAX3 in soybean. Symbiosis 2019, 77, 9-21. [CrossRef]

35. De Sousa, A.; AbdElgawad, H.; Asard, H.; Pinto, A.; Soares, C.; Branco-Neves, S.; Braga, T.; Azenha, M.; Selim, S.; Al Jaouni, S.; et al. Metalaxyl Effects on Antioxidant Defenses in Leaves and Roots of Solanum nigrum L. Front. Plant Sci. 2017, 8, 1967. [CrossRef] [PubMed]

36. Khan, A.L.; Gilani, S.A.; Waqas, M.; Al-Hosni, K.; Al-Khiziri, S.; Kim, Y.-H.; Ali, L.; Kang, S.-M.; Asaf, S.; Shahzad, R.; et al. Endophytes from medicinal plants and their potential for producing indole acetic acid, improving seed germination and mitigating oxidative stress. J. Zhejiang Univ. Sci. B 2017, 18, 125-137. [CrossRef]

37. Jan, R.; Khan, M.A.; Asaf, S.; Lubna; Lee, I.-J.; Kim, K.M. Metal Resistant Endophytic Bacteria Reduces Cadmium, Nickel Toxicity, and Enhances Expression of Metal Stress Related Genes with Improved Growth of Oryza sativa, via Regulating Its Antioxidant Machinery and Endogenous Hormones. Plants 2019, 8, 363. [CrossRef]

38. Khan, M.A.; Asaf, S.; Khan, A.L.; Jan, R.; Kang, S.-M.; Kim, K.-M.; Lee, I.-J. Extending thermotolerance to tomato seedlings by inoculation with SA1 isolate of Bacillus cereus and comparison with exogenous humic acid application. PLoS ONE 2020, 15, e0232228. [CrossRef]

39. Juteau, P. Review of the use of aerobic thermophilic bioprocesses for the treatment of swine waste. Livest. Sci. 2006, 102, 187-196. [CrossRef]

40. Hamayun, M.; Afzal Khan, S.; Khan, A.; Shinwari, Z.; Hussain, J.; Sohn, E.-Y.; Kang, S.-M.; Kim, Y.-H.; Khan, M.; Lee, I.-J. Effect of salt stress on growth attributes and endogenous growth hormones of soybean cultivar Hwangkeumkong. Abstr. Pap. 2010, 42, 3103-3112.

41. Hamayun, M.; Sohn, E.-Y.; Afzal Khan, S.; Shinwari, Z.; Khan, A.; Lee, I.-J. Silicon alleviates the adverse effects of salinity and drought stress on growth and endogenous plant growth hormones of soybean (Glycine max L.). Abstr. Pap. 2010, 42, $1713-1722$. 
42. Hamayun, M.; Khan, S.A.; Khan, A.L.; Shin, J.H.; Ahmad, B.; Shin, D.H.; Lee, I.J. Exogenous gibberellic acid reprograms soybean to higher growth and salt stress tolerance. J. Agric. Food Chem. 2010, 58, 7226-7232. [CrossRef]

43. Hamayun, M.; Hussain, A.; Khan, S.A.; Kim, H.-Y.; Khan, A.L.; Waqas, M.; Irshad, M.; Iqbal, A.; Rehman, G.; Jan, S.; et al. Gibberellins Producing Endophytic Fungus Porostereum spadiceum AGH786 Rescues Growth of Salt Affected Soybean. Front. Microbiol. 2017, 8, 686. [CrossRef]

44. Khan, A.L.; Waqas, M.; Hamayun, M.; Al-Harrasi, A.; Al-Rawahi, A.; Lee, I.-J. Co-synergism of endophyte Penicillium resedanum LK6 with salicylic acid helped Capsicum annuumin biomass recovery and osmotic stress mitigation. BMC Microbiol. 2013, 13, 51. [CrossRef]

45. Kang, S.-M.; Khan, A.; Waqas, M.; You, Y.-H.; Kim, J.-H.; Kim, J.-G.; Hamayun, M.; Lee, I.-J. Plant Growth Promoting Rhizobacterias reduces adverse effects of salinity and osmotic stress by regulating phytohormones and antioxidants in Cucumis sativus. J. Plant Interact. 2014, 9. [CrossRef]

46. Egamberdieva, D.; Berg, G.; Lindström, K.; Räsänen, L.A. Alleviation of salt stress of symbiotic Galega officinalis L. (goat's rue) by co-inoculation of Rhizobium with root-colonizing Pseudomonas. Plant Soil 2013, 369, 453-465. [CrossRef]

47. Nautiyal, C.S.; Srivastava, S.; Chauhan, P.S.; Seem, K.; Mishra, A.; Sopory, S.K. Plant growth-promoting bacteria Bacillus amyloliquefaciens NBRISN13 modulates gene expression profile of leaf and rhizosphere community in rice during salt stress. Plant Physiol. Biochem. 2013, 66, 1-9. [CrossRef]

48. Yoo, S.-J.; Weon, H.-Y.; Song, J.; Sang, M.K. Induced tolerance to salinity stress by halotolerant bacteria Bacillus aryabhattai H19-1 and B. mesonae H20-5 in tomato plants. J. Microbiol. Biotechnol. 2019, 29, 1124-1136. [CrossRef]

49. Siddikee, M.A.; Glick, B.R.; Chauhan, P.S.; jong Yim, W.; Sa, T. Enhancement of growth and salt tolerance of red pepper seedlings (Capsicum annuиm L.) by regulating stress ethylene synthesis with halotolerant bacteria containing 1-aminocyclopropane-1carboxylic acid deaminase activity. Plant Physiol. Biochem. 2011, 49, 427-434. [CrossRef]

50. Hidri, R.; Barea, J.M.; Mahmoud, O.M.-B.; Abdelly, C.; Azcón, R. Impact of microbial inoculation on biomass accumulation by Sulla carnosa provenances, and in regulating nutrition, physiological and antioxidant activities of this species under non-saline and saline conditions. J. Plant Physiol. 2016, 201, 28-41. [CrossRef]

51. Assaha, D.V.M.; Ueda, A.; Saneoka, H.; Al-Yahyai, R.; Yaish, M.W. The Role of $\mathrm{Na}(+)$ and $\mathrm{K}(+)$ Transporters in Salt Stress Adaptation in Glycophytes. Front. Physiol. 2017, 8, 509. [CrossRef]

52. Al-Karaki, G.N. Growth of mycorrhizal tomato and mineral acquisition under salt stress. Mycorrhiza 2000, 10, 51-54. [CrossRef]

53. Kohler, J.; Hernández, J.A.; Caravaca, F.; Roldán, A. Induction of antioxidant enzymes is involved in the greater effectiveness of a PGPR versus AM fungi with respect to increasing the tolerance of lettuce to severe salt stress. Environ. Exp. Bot. 2009, 65, 245-252. [CrossRef]

54. Hashem, A.; Abd_Allah, E.F.; Alqarawi, A.A.; Aldubise, A.; Egamberdieva, D. Arbuscular mycorrhizal fungi enhances salinity tolerance of Panicum turgidum Forssk by altering photosynthetic and antioxidant pathways. J. Plant Interact. 2015, 10, $230-242$. [CrossRef]

55. Shilev, S. Plant-Growth-Promoting Bacteria Mitigating Soil Salinity Stress in Plants. Appl. Sci. 2020, 10, 7326. [CrossRef]

56. Mayak, S.; Tirosh, T.; Glick, B.R. Plant growth-promoting bacteria confer resistance in tomato plants to salt stress. Plant Physiol. Biochem. 2004, 42, 565-572. [CrossRef]

57. Panwar, M.; Tewari, R.; Nayyar, H. Native halo-tolerant plant growth promoting rhizobacteria Enterococcus and Pantoea sp. improve seed yield of Mungbean (Vigna radiata L.) under soil salinity by reducing sodium uptake and stress injury. Physiol. Mol. Biol. Plants 2016, 22, 445-459. [CrossRef]

58. Zhang, L.; Lin, Q.; Feng, Y.; Fan, X.; Zou, F.; Yuan, D.-Y.; Zeng, X.; Cao, H. Transcriptomic Identification and Expression of Starch and Sucrose Metabolism Genes in the Seeds of Chinese Chestnut (Castanea mollissima). J. Agric. Food Chem. 2015, 63, 929-942. [CrossRef]

59. Liu, Q.; Li, J.; Liu, W. Sugar accumulation and characterization of metabolizing enzyme genes in leafy head of Chinese cabbage (Brassica campestris L. ssp. pekinensis). Hortic. Environ. Biotechnol. 2021, 62, 17-29. [CrossRef]

60. Kang, S.-M.; Radhakrishnan, R.; Lee, S.-M.; Park, Y.-G.; Kim, A.-Y.; Seo, C.-W.; Lee, I.-J. Enterobacter sp. SE992-induced regulation of amino acids, sugars, and hormones in cucumber plants improves salt tolerance. Acta Physiol. Plant. 2015, 37, 149. [CrossRef]

61. Liu, H.; Chen, X.; Song, L.; Li, K.; Zhang, X.; Liu, S.; Qin, Y.; Li, P. Polysaccharides from Grateloupia filicina enhance tolerance of rice seeds (Oryza sativa L.) under salt stress. Int. J. Biol. Macromol. 2019, 124, 1197-1204. [CrossRef]

62. Chinsamy, M.; Kulkarni, M.G.; Van Staden, J. Garden-waste-vermicompost leachate alleviates salinity stress in tomato seedlings by mobilizing salt tolerance mechanisms. Plant Growth Regul. 2013, 71, 41-47. [CrossRef]

63. Talaat, N.B.; Shawky, B.T. Protective effects of arbuscular mycorrhizal fungi on wheat (Triticum aestivum L.) plants exposed to salinity. Environ. Exp. Bot. 2014, 98, 20-31. [CrossRef]

64. Wu, Z.; Peng, Y.; Guo, L.; Li, C. Root colonization of encapsulated Klebsiella oxytoca Rs-5 on cotton plants and its promoting growth performance under salinity stress. Eur. J. Soil Biol. 2014, 60, 81-87. [CrossRef]

65. Khan, M.A.; Asaf, S.; Khan, A.L.; Adhikari, A.; Jan, R.; Ali, S.; Imran, M.; Kim, K.M.; Lee, I.J. Plant growth-promoting endophytic bacteria augment growth and salinity tolerance in rice plants. Plant Biol. 2020, 22, 850-862. [CrossRef]

66. Ait-El-Mokhtar, M.; Baslam, M.; Ben-Laouane, R.; Anli, M.; Boutasknit, A.; Mitsui, T.; Wahbi, S.; Meddich, A. Alleviation of Detrimental Effects of Salt Stress on Date Palm (Phoenix dactylifera L.) by the Application of Arbuscular Mycorrhizal Fungi and/or Compost. Front. Sustain. Food Syst. 2020, 4, 131. [CrossRef] 
67. Raja, V.; Majeed, U.; Kang, H.; Andrabi, K.I.; John, R. Abiotic stress: Interplay between ROS, hormones and MAPKs. Environ. Exp. Bot. 2017, 137, 142-157. [CrossRef]

68. Fahad, S.; Hussain, S.; Matloob, A.; Khan, F.A.; Khaliq, A.; Saud, S.; Hassan, S.; Shan, D.; Khan, F.; Ullah, N. Phytohormones and plant responses to salinity stress: A review. Plant Growth Regul. 2015, 75, 391-404. [CrossRef]

69. Zahra, S.; Amin, B.; Ali, V.S.M.; Ali, Y.; Mehdi, Y. The salicylic acid effect on the tomato (Lycopersicum esculentum Mill.) sugar, protein and proline contents under salinity stress (NaCl). J. Biophys. Struct. Biol. 2011, 2, 35-41.

70. Ahanger, M.A.; Agarwal, R. Salinity stress induced alterations in antioxidant metabolism and nitrogen assimilation in wheat (Triticum aestivum L.) as influenced by potassium supplementation. Plant Physiol. Biochem. 2017, 115, 449-460. [CrossRef]

71. Caverzan, A.; Casassola, A.; Brammer, S.P. Reactive oxygen species and antioxidant enzymes involved in plant tolerance to stress. In Abiotic and Biotic Stress in Plants—Recent Advances and Future Perspectives; Shanker, A.K., Shanker, C., Eds.; IntechOpen: London, UK, 2016; pp. 463-480.

72. Laouane, R.B.; Meddich, A.; Bechtaoui, N.; Oufdou, K.; Wahbi, S. Effects of arbuscular mycorrhizal fungi and rhizobia symbiosis on the tolerance of Medicago sativa to salt stress. Gesunde Pflanz. 2019, 71, 135-146. [CrossRef] 